\title{
Direct Effect of cashew Nut Scarification Associated with Powdery Mildew in the Processing Industry
}

\author{
Americo Uaciquete \\ Instituto de Investigação Agraria de Moçambique, \\ IIAM-Posto Agronómico de Nampula, Centro Zonal Nordeste \\ Rua de Corrane, Km7, C.P. 623; Telf. +258 824062230; Fax. 25826240268 \\ Jacinto Raul Nicurrupo \\ Instituto de Fomento do Caju \\ Av. 25 de Setembro no. 1198/1200 \\ Caixa Postal No. 177 \\ Nampula, Mozambique \\ Telf. +258 84 9124487; Fax no. +25826213192 \\ Received: March 29, 2016 Accepted: April 12, $2016 \quad$ Published: August 12, 2016 \\ doi:10.5296/jas.v4i3.9881ＵRL: http://dx.doi.org/10.5296/jas.v4i3.9881
}

\begin{abstract}
Cashew powdery mildew disease can reduce on field yield by $100 \%$ depending on flowers' susceptibility. Surviving flowers may still produce nuts that are severely damaged. The impact of this, post-harvest, damage to the processing industry is unknown. Therefore the objective of this experiment was to assess the effect of powdery mildew nut scarification on biometric and industrial processing variables: nut size, weight, nut count, outturn, cutting and peeling time and finally analyze the financial implication of the effect. Thus, raw cashew nuts were randomly sampled and categorized in to five disease score levels (treatments). Ten nuts (replicates) were used for each disease category. Length, thickness, width and weight were measured. Furthermore, from each disease level, two sets of nuts were established. One set for nut count and outturn assessment by cutting test. The other set, for steam boiling, cutting, peeling and other processes quantitatively assessed. A completely randomized experimental design was followed for data analysis. The summary effect was assessed as relative loss in percentage to non diseased nuts. The relative maximum loss due to powdery mildew attack was $41.2 \%$ for nut length, $42.9 \%$ for nut width, $31.3 \%$ for nut thickness and $50 \%$ for nut weight. The disease severity increased relative nut count $(18.9 \%)$ and reduced the total
\end{abstract}


percentage of kernels $(20.3 \%)$, outturn $(21.1 \%)$, the industrial yield of white wholes $(88.1 \%)$, amount of peels $(27.6 \%)$ and the outturn and nut count based projected income by $9.6 \%$. Three disease based nut categories are proposed for processing improvements. Nut scarification effect on kernel deterioration, seed germination and others is under investigation.

Keywords: oidium anacardii, cashew industrial processing, anacardium occidentale

\section{Introduction}

Cashew (Anacardium occidentale L.) is native to North East Brazil (Mitchell and Mori, 1987; Dendena and Corsi, 2014). But, the crop is well adapted in regions between Cancer and Capricorn Tropics and coastal areas of India, Africa and Latin America (Pessoa et al., 2003; Adeigbe et al., 2015). It is from Brazil that powdery mildew (Oidium anacardii Noack) was recorded for the first time (Martin et al., 1997; Serrano et al., 2013). Today, the disease is known to occur in most cashew growing areas of the world (Ohler, 1979; Intini, 1987; Shomari, 1996; Uaciquete, 2004; Zhongrun et al., 2013). However, severe damages have been reported mainly from East Africa (Waller et al., 1992; Shomari and Kennedy, 1999; Serrano et al., 2013).

Research efforts from 1990's focused on pre-harvest aspects such as description of disease symptoms (Waller et al., 1992; Shomari and Kennedy, 1999), development of disease assessment methods (Nathaniels, 1996), understanding of the disease epidemiology (Martin et al., 1997; Shomari and Kennedy, 1999) and development of on-field disease management strategies (Caligari, 1997; Martin et al., 1997; Smith et al., 1997; Kasuga et al., 1998; Topper et al., 1998; Sijaona and Mansfield, 1999). Meanwhile, very little information is found on post-harvest studies of the disease. Topper et al., (2000) reported 5\% reduction in nut quality measured by shelling outturn. Later, Serrano et al., (2013), based on a number of nut biometric parameters, established that powdery mildew has a negative impact that varied with host genotypes. Mneney (2013), highlighted the prospectus of using molecular technologies for selection of genotypes tolerant to powdery mildew. Nevertheless, looking at the amount of pre-harvest research output, it suggests that the impact of the disease is mostly on farmers. Unless the whole industry comes to understand the impact of the disease, the issue will remain among the researchers, farmers and pesticides related companies.

In this work, we aimed at determining the impact of powdery mildew nut scarification on industrial processing parameters. Specifically, the experiment intended to find out how the disease affects the nut length, thickness, width, weight, nut count, outturn, kernel industrial yield, cutting and peeling time and finally analyze the financial implication of the disease effect and produce appropriate recommendations.

\section{Material and Methods}

\subsection{Disease severity and nut categories}

Raw cashew nuts harvested during the 2014/15 crop season were randomly sampled from the warehouse $80 \mathrm{~kg}$ bags, at Nassuruma Cashew Research Center, Nampula, Mozambique (14S 
58 ' 48" and 39E 44' 55"). The nuts were individually and visually categorized (Table 1) following a five levels scoring system illustrated in Plate 1.

Table 1. Categories of powdery mildew (Oidium anacardii) severity on cashew nut, their description and treatment codes.

\begin{tabular}{|c|c|c|}
\hline Category (\%) & Description & Treatment code \\
\hline 0 & Clean nut, with no scarification & 1 \\
\hline ]0-25] & Up to a quarter of the nut surface scarified & 2 \\
\hline ]25-50] & $\begin{array}{l}\text { More than a quarter, but not more than a half } \\
\text { of the nut surface scarified }\end{array}$ & 3 \\
\hline ]50-99] & $\begin{array}{l}\text { More than half, but not whole nut surface } \\
\text { scarified }\end{array}$ & 4 \\
\hline 100 & Whole nut surface scarified & 5 \\
\hline
\end{tabular}

Nuts from each category (treatment) were separated into one kilogram containers. Three sets were prepared: One for biometric measurements of individual nuts, a second set for cutting test and outturn estimation and a third set for steam boiling and assessment of industrial variables. All nuts were transported to a private cashew company for processing (CondorNuts, Anchilo, Nampula). 


\section{Macrothink}

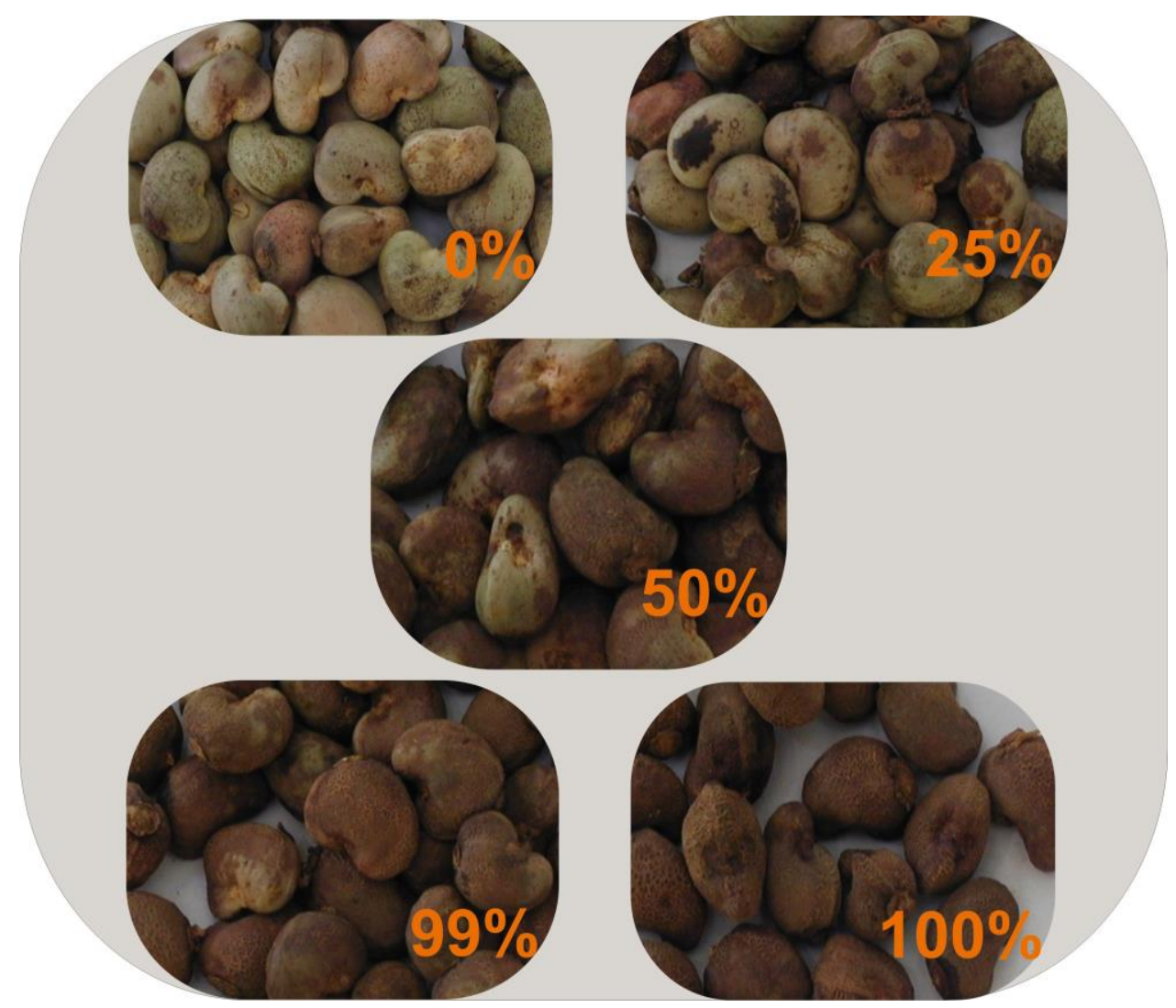

Plate 1. Standard photos 0-4, showing cashew powdery mildew scarified nuts (Oidium anacardii Noack): $0=$ no scarification; $1=] 0-25 \%] ; 2=] 25-50 \%] ; 3=] 50$ $-99 \%] ; 4=100 \%$. Modified from Nathaniels, 1996.

\subsection{Experimental design}

For biometric measurements of nuts, the experiment was planned as completely randomized design (Petersen, 1994) with 5 treatments (disease score levels) and 10 replicates consisting of single nut each. Measurements on individual nut size (nut length, width and thickness) were taken using a mill metric caliper and a weighing scale (Ogunsina and Bamgboye, 2007; Serrano et al., 2013). This part of the experiment was repeated nine times.

For nut count and shelling outturn test and all the industrial processing steps from steam boiling to peeling (Dendena and Corsi, 2014), the same CRD design (Petersen, 1994) was followed. Five treatments (disease score levels) and three replicates consisting of one kilogram each were considered. This part of the trial was repeated three times.

\subsection{Industrial measurements}

\subsubsection{Nut count and outturn}

Considering one set of nuts, from each replicate (one kilogram) all units were counted and recorded in appropriate form. After that, the cutting test for outturn was performed following the international procedures of weighed proportion of quality nuts given in pounds (Ogunsina, 2013) and percentage (Kasuga, 2013). 


\subsubsection{Nut boiling and other variable assessment}

Special wire nests for one kilogram of nuts each were prepared and filled with nuts of each replicate and category. Metallic tags were used to indicate treatments and replicates. All nuts were steam boiled together with other nuts being processed at the factory. That is, steam boiling for 10 minutes. After steaming, the nuts were maintained in open air for 24 hours for cooling. Four best workers were chosen and attributed five kilograms of boiled cashew nuts to perform the cutting and separation of kernels. Each worker played a role of replicate and a kilogram of nuts (treatment) was randomly allocated at a time. Maintaining the tags, kernels were then oven dried at $70^{\circ} \mathrm{C}$ for 24 hours as routinely done at the factory. After oven drying, the kernels were then distributed, among the four best workers in the peeling section. The weight of peels and kernels for each replicate and treatment was recorded and kernels classified as normally practiced at the factory before packing for international market. The percentage $(\mathrm{g} / \mathrm{g})$ of kernels was recorded following the industrial categories of kernels: wholes, rotten, spotted and others.

\subsubsection{Data analysis}

For all variables, an analysis of variance (ANOVA) was performed in Statistical Analysis System, version 9.0 (SAS, 2002). Data from each nut set, where normally distributed with homogenous treatment variances. Thus, for each experimental, data were pooled for combined analysis and treatment mean comparison was made by least significant difference test at 0.05 probabilities (Petersen, 1994). Variable means were then plotted graphically where necessary.

Percentage relative maximum loss (REMALOS) due to disease effect for each variable was estimated as follows: The effect at maximum nut scarification (EMAS) was subtracted to the effect at minimum nut scarification (EMIS). The result was then divided by the effect at maximum nut scarification (EMAS) and finally retrieved as percentage by multiplying by 100 .

$$
\text { REMALOS }=[(\text { EMAS-EMIS }) / E M A S] * 100
$$

Three disease related categories (clean, mixed and diseased) where established by retrieving arithmetical means for nut count (Figure 8A) and outturn (Figure 8C) as per their statistical groups.

By placing potential outturn values in a table together with the corresponding international nut price (Figure 9B), the effect of the disease on nut price was projected.

\section{Results}

\subsection{Effect of powdery mildew on nut length, width, thickness and weight}

Table 2. Analysis of variance (ANOVA) of four biometric nut variables from cashew nut experiment

\begin{tabular}{ccccccc}
\hline Variable & $\begin{array}{l}\text { Source of } \\
\text { variation }\end{array}$ & Df & SS & MS & F Value & CV (\%) \\
\hline
\end{tabular}




\begin{tabular}{|c|c|c|c|c|c|c|}
\hline & Error & 445 & 46688.8222 & 104.9187 & & \\
\hline \multirow[t]{2}{*}{ Nut length } & $\begin{array}{c}\text { Disease severity } \\
\text { Total }\end{array}$ & $\begin{array}{c}4 \\
449\end{array}$ & $\begin{array}{l}13585.6578 \\
60274.4800\end{array}$ & 3396.41444 & $32.37 * * *$ & 35.9 \\
\hline & Error & 445 & 18829.2111 & 42.3128 & & \\
\hline \multirow[t]{2}{*}{ Nut width } & $\begin{array}{c}\text { Disease severity } \\
\text { Total }\end{array}$ & $\begin{array}{c}4 \\
449\end{array}$ & $\begin{array}{r}5637.68 \\
24466.8911\end{array}$ & 1409.42 & $33.31 * * *$ & 36.3 \\
\hline & Error & 445 & 14510.1333 & 32.6070 & & \\
\hline \multirow[t]{2}{*}{ Nut thickness } & $\begin{array}{c}\text { Disease severity } \\
\text { Total }\end{array}$ & $\begin{array}{c}4 \\
449 \\
\end{array}$ & $\begin{array}{c}1614.4978 \\
16124.6311 \\
\end{array}$ & 403.6244 & $12.38 * * *$ & 38.9 \\
\hline & Error & 445 & 2342.2711 & 5.2635 & & \\
\hline Nut weight & $\begin{array}{c}\text { Disease severity } \\
\text { Total }\end{array}$ & $\begin{array}{c}4 \\
449\end{array}$ & $\begin{array}{c}1381.327467 \\
3723.5986\end{array}$ & 345.3319 & $65.61 * * *$ & 36.4 \\
\hline
\end{tabular}

*** Significant at 5\% level; DF=degrees of freedom; $\mathrm{SS}=$ Sum of Squares; MS=Mean Square; FValue $=$ Fisher Value; $\mathrm{CV}=$ Coefficient of variation in percentage.

Analysis of nut length, width, thickness and weight, indicate that there are highly significant differences in nut size among the five severity levels of powdery severity established in the experiment. The variable mean results are presented in Table 3.

Table 3. Effect of powdery mildew (Oidium anacardii Noack) severity on nut length, width, thickness and weight

Biometric variables of cashew nuts

\begin{tabular}{ccccc}
\cline { 2 - 5 } Disease severity on nuts (\%) & Length $(\mathbf{m m})$ & Width $(\mathbf{m m})$ & Thickness $(\mathbf{m m})$ & Weight $(\mathbf{g})$ \\
\hline 0 & $34.244 \pm 0.334 \mathrm{a}$ & $21.5333 \pm 0.240 \mathrm{a}$ & $16.7667 \pm 0.161 \mathrm{a}$ & $8.3144 \pm 0.145 \mathrm{a}$ \\
] $0-25]$ & $34.100 \pm 0.336 \mathrm{a}$ & $21.5111 \pm 0.262 \mathrm{a}$ & $16.3444 \pm 0.174 \mathrm{ab}$ & $8.0811 \pm 0.148 \mathrm{a}$ \\
{$[25-50]$} & $29.678 \pm 1.143 \mathrm{~b}$ & $18.7667 \pm 0.731 \mathrm{~b}$ & $15.0222 \pm 0.588 \mathrm{bc}$ & $6.4189 \pm 0.275 \mathrm{~b}$ \\
{$[50-99]$} & $24.156 \pm 1.389 \mathrm{c}$ & $15.0667 \pm 0.872 \mathrm{c}$ & $13.6778 \pm 0.793 \mathrm{c}$ & $4.8356 \pm 0.289 \mathrm{c}$ \\
100 & $20.356 \pm 1.539 \mathrm{~d}$ & $12.6444 \pm 0.964 \mathrm{~d}$ & $11.5667 \pm 0.883 \mathrm{~d}$ & $3.8589 \pm 0.300 \mathrm{~d}$ \\
\hline
\end{tabular}

Means \pm standard error, followed by the same letter vertically, are not statistically different by Fisher's LSD test at 5\% probability. $\mathrm{mm}=$ millimeters; $\mathrm{g}=$ grams; $\%=$ percentage

All variables measured, nut length, width, thickness and weight, were significantly reduced by powdery mildew nut scarification above $25 \%$ (Table 2). The relative maximum loss (REMALOS) due to powdery mildew attack was estimated as $41.2 \%$ in nut length, $42.9 \%$ for nut width, $31.3 \%$ for nut thickness and $50 \%$ for nut weight. 


\subsection{Analysis of variance (ANOVA)}

Table 4. Analysis of variance (ANOVA) for various industrial variables from a cashew nut processing yield evaluation experiment

\begin{tabular}{|c|c|c|c|c|c|c|}
\hline Variable & $\begin{array}{l}\text { Source of } \\
\text { variation }\end{array}$ & Df & SS & MS & Fvalue & $\mathrm{CV}(\%)$ \\
\hline \multirow{4}{*}{ Nut Count } & Disease Severity & 4 & 12564.5667 & 3141.142 & $5.52 * * *$ & \\
\hline & Error & 55 & 3127.1667 & 568.5667 & & \\
\hline & Total & 59 & 43835.7333 & & & \\
\hline & & & & & & 13.8 \\
\hline \multirow{4}{*}{ Outturn } & Disease Severity & 4 & 783.1272 & 195.7818 & $14.54 * * *$ & \\
\hline & Error & 55 & 740.7538 & 13.4683 & & \\
\hline & Total & 59 & 1523.881 & & & \\
\hline & & & & & & 8.7 \\
\hline \multirow{4}{*}{ Premature kernels } & Disease Severity & 4 & 251.6083 & 62.9021 & $1.79 \mathrm{NS}$ & \\
\hline & Error & 55 & 1932.375 & 35.1341 & & \\
\hline & Total & 59 & 2183.9833 & & & \\
\hline & & & & & & 32.9 \\
\hline \multirow{3}{*}{ Spotted kernels } & Disease Severity & 4 & 252.9 & 62.225 & $4.95 * * *$ & \\
\hline & Error & 55 & 702.75 & 12.7773 & & \\
\hline & Total & 59 & 955.65 & & & \\
\hline
\end{tabular}

52.2

Significant at 5\% level by Fisher's LSD test; NS= Not significant at 5\% level; $\mathrm{Df}=$ degrees of freedom; $\mathrm{SS}=$ Sum of Squares; MS= Mean Square; Fvalue= Fisher value; $\mathrm{CV}=$ Coefficient of variation in percentage.

Table 4. Analysis of variance (ANOVA) for various industrial variables from a cashew nut processing yield evaluation experiment (Continued)

\begin{tabular}{llllllr}
\hline Variable & $\begin{array}{l}\text { Source of } \\
\text { variation }\end{array}$ & Df & SS & MS & Fvalue & CV(\%) \\
\hline \multirow{3}{*}{ Total kernel yield } & Disease Severity & 4 & 1595.2717 & 398.8179 & $4.75^{* * *}$ & \\
& Error & 55 & 4621.7117 & 84.0311 & & \\
& Total & 59 & 6216.9833 & & & 51.2 \\
\hline \multirow{3}{*}{$\begin{array}{l}\text { White wholes kernel } \\
\text { Yield }\end{array}$} & Disease Severity & 4 & 3565.334 & 891.3335 & $15.63^{* * *}$ & \\
& Error & 55 & 3137.2425 & 57.0408 & & \\
& Total & 59 & 67702.5765 & & & 55.5 \\
\hline \multirow{3}{*}{ Percentage of peels } & Disease Severity & 4 & 45.8895 & 11.4724 & $6.48^{* * *}$ & \\
& Error & 39 & 69.0983 & 1.7718 & & \\
& Total & 43 & 114.9879 & & & 14.7 \\
\hline \multirow{3}{*}{ Rotten kernels } & Disease Severity & 4 & 8.8063 & 2.2016 & $7.04 * * *$ & \\
& Error & 55 & 17.1913 & 0.3126 & & \\
& Total & 59 & 25.9976 & & & 57.3
\end{tabular}

*** Significant at 5\% level by Fisher's LSD test; NS= Not significant at 5\% level; 


\section{Al Macrothink}

Journal of Agricultural Studies

ISSN 2166-0379

2016, Vol. 4, No. 3

$\mathrm{Df}=$ degrees of freedom; $\mathrm{SS}=\mathrm{Sum}$ of Squares; MS= Mean Square; Fvalue= Fisher value; $\mathrm{CV}=$ Coefficient of variation in percentage.

Analysis of data from various industrial variables (Table 4) on cashew nuts processing, indicate that there are highly significant differences in all of them except for percentage of premature kernels. Thus the five severity levels of powdery severity were established as the cause of variation in the experiment. Mean test results are presented in the following sections.

\subsection{Effect of powdery mildew on nut count}

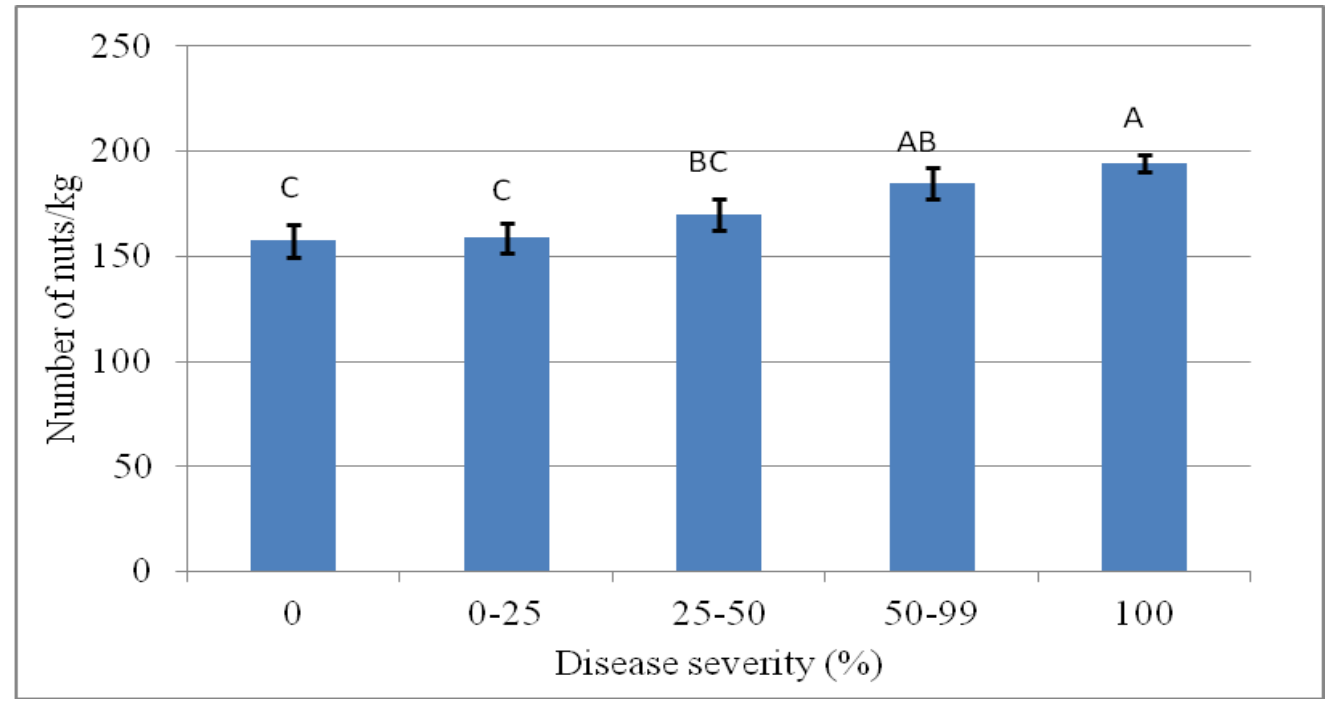

Figure 1. Effect of nut scarification associated with powdery mildew (Oidium anacardii Noack) on the number of cashew nuts per kilogram. Same letter on top of the bar means that nut scarification levels (treatment) were not statistically different by Fisher's LSD test. Little bars on top of the others, represent standard errors of the mean.

Nut scarification associated with powdery mildew disease resulted in increased nut from almost 157 nuts per kilogram to about 194 units per kilogram (Figure 1). The relative maximum increase in nut count was $18.9 \%$.

3.4 Effect of powdery mildew on nut shelling outturn

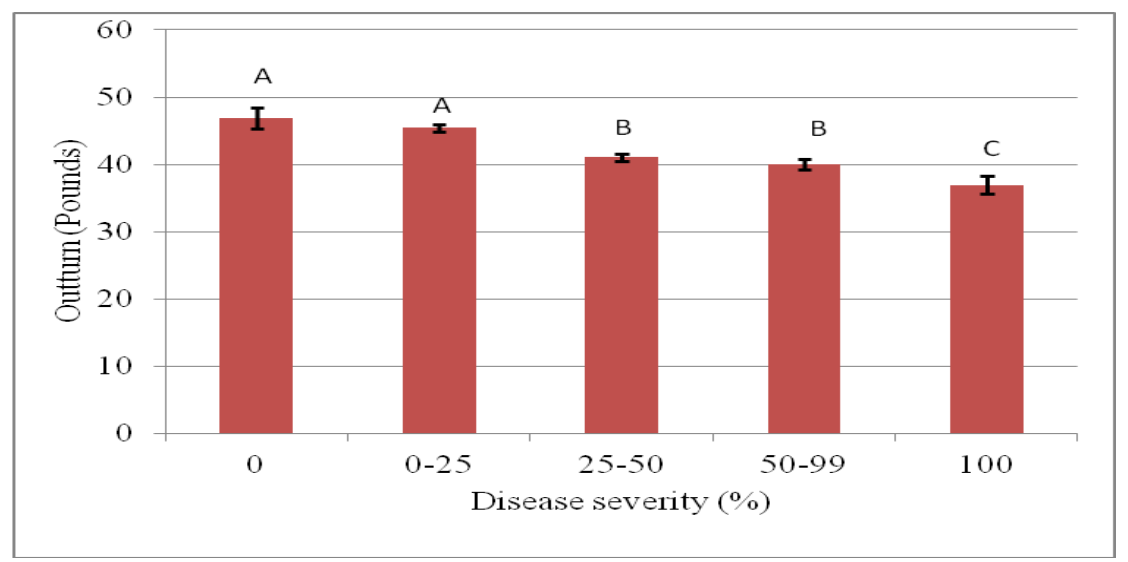




\section{Macrothink}

Figure 2: Effect of nut scarification associated with powdery mildew (Oidium anacardii Noack) on shelling outturn. Same letter on top of the bar means that outturn means were not statistically different by Fisher's LSD test at alpha $=0.05$. Little bars on top of the others represent standard errors of the mean.

Powdery mildew disease, measured as nut scarification, significantly decreased the shelling outturn from about 47 to 37 pounds (Figure 2). Nuts with surface scarification at $100 \%$ had the lowest outturn of 37 pounds approximately (Figure 2). At this level of nut scarification (Figure 2), about $21.1 \%$ relative maximum loss on shelling outturn was observed.

\subsection{Effect of powdery mildew on total kernel yield}

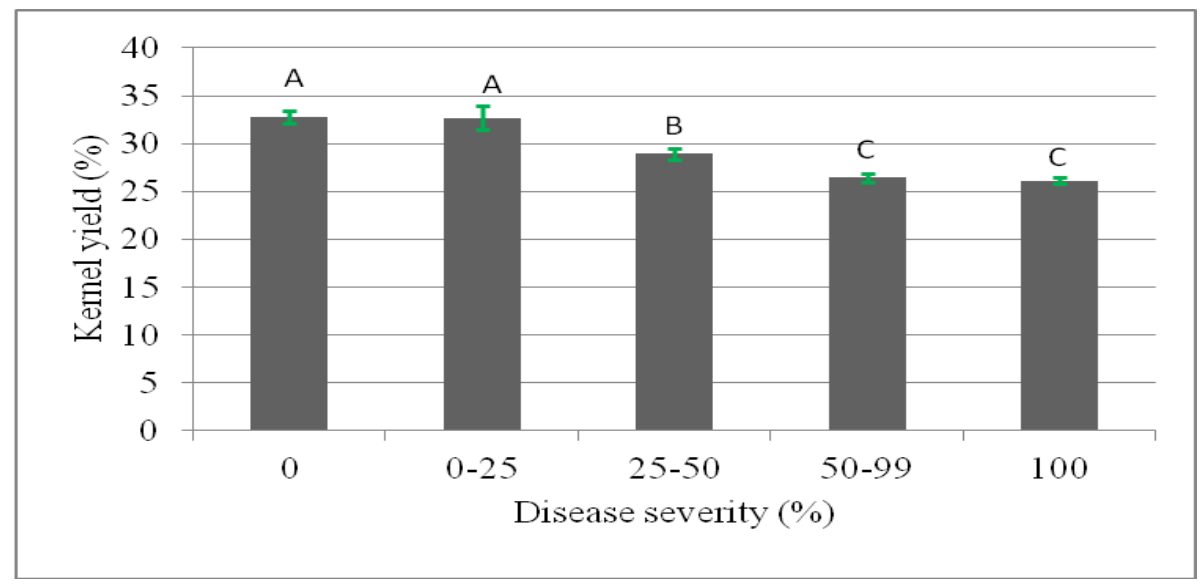

Figure 3. Effect of nut scarification associated with powdery mildew (Oidium anacardii Noack) on kernel industrial yield (\%). Same letter on top of the bar means that percentage kernel means were not statistically different by Fisher's LSD test at alpha $=0.05$. Little bars on top of the others represent standard errors of the mean.

Powdery mildew disease reduced the industrial yield of kernels from 33 to 26\% (Figure 3). In the extreme scenario of the disease, $100 \%$ nut surface scarification (Figure 3), the relative maximum loss is estimated at $20.3 \%$.

\subsection{Effect of powdery mildew on white wholes}

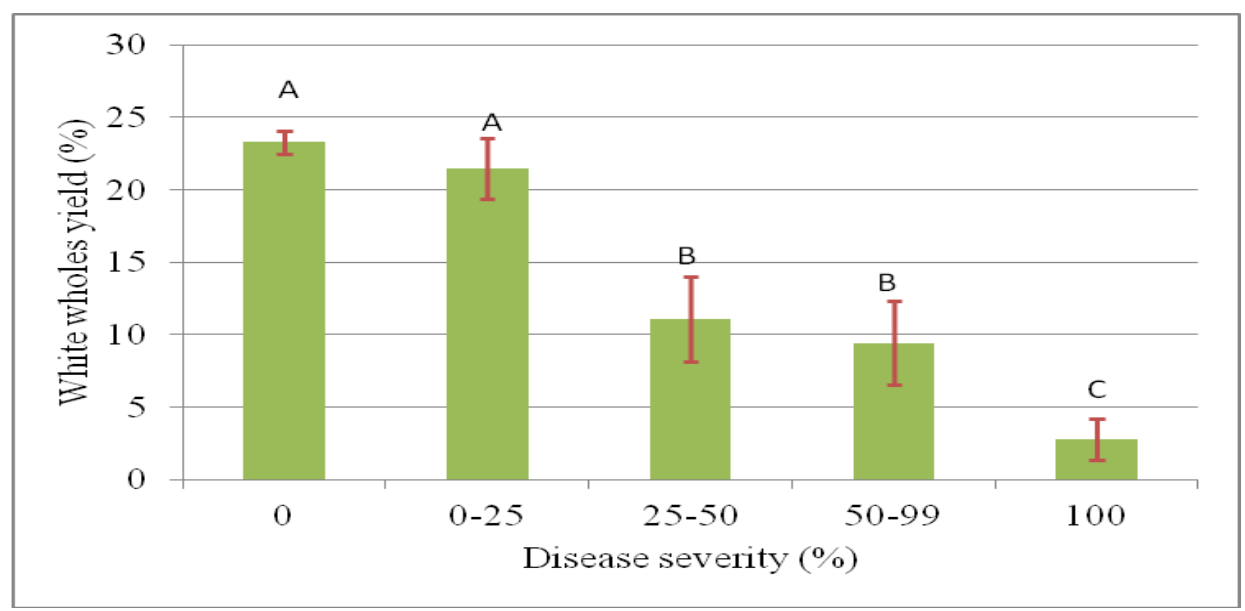




\section{Macrothink}

Figure 4. Effect of nut scarification associated with powdery mildew (Oidium anacardii Noack) on white wholes industrial yield. Same letter on top of the bar means that percentage means of white wholes kernels were not statistically different by Fisher's LSD test at alpha $=0.05$. Little bars on top of the others represent standard errors of the mean.

Powdery mildew disease reduced the industrial yield of white wholes kernels from about 23 to $3 \%$ (Figure 4). Thus, the relative maximum loss in white wholes, from clean nuts $(0 \%)$ to highly scarified nuts (100\%) is estimated at $88 \%$.

\subsection{Effect of powdery mildew on spotted and rotten kernels}

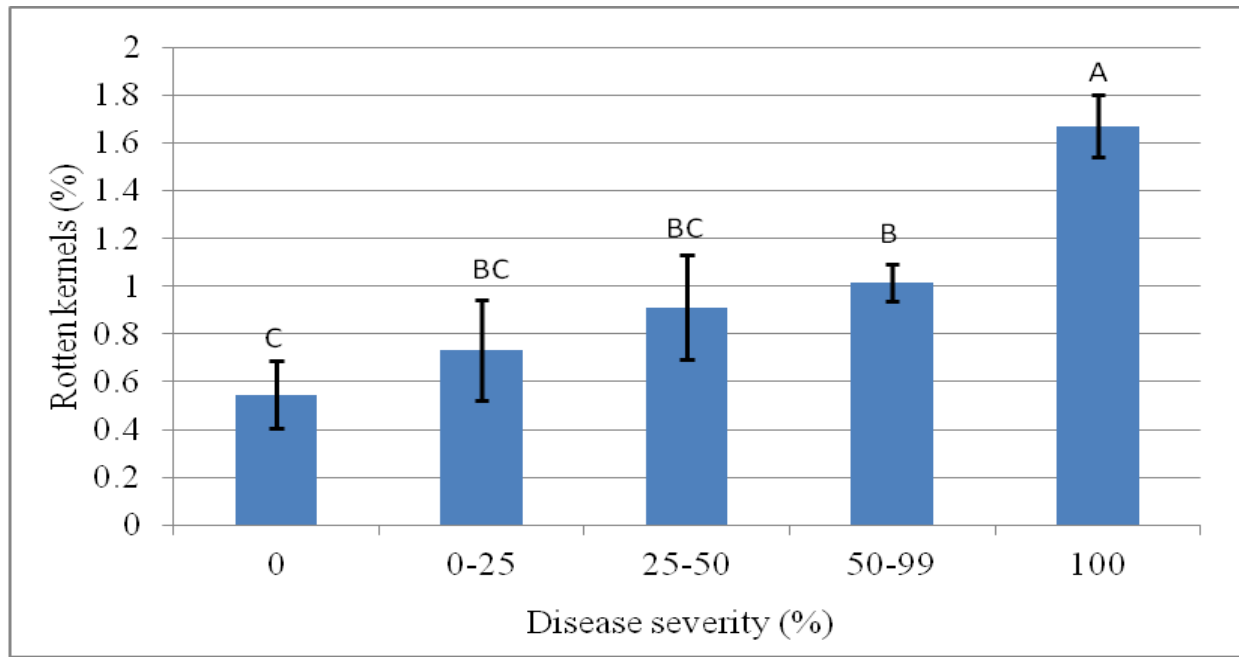

Figure 5. Effect of nut scarification associated with powdery mildew (Oidium anacardii Noack) on percentage of rotten kernels. Same letter on top of the bar means that percentage means were not statistically different by Fisher's LSD test at alpha $=0.05$. Little bars on top of the others represent standard errors of the mean.

The percentage of rotten kernels increased significantly with increase on nut surface scarification (Figure 5). Highest percentage of rotten kernels observed was around $1 \%$ at maximum disease severity (100\%) (Figure 5).

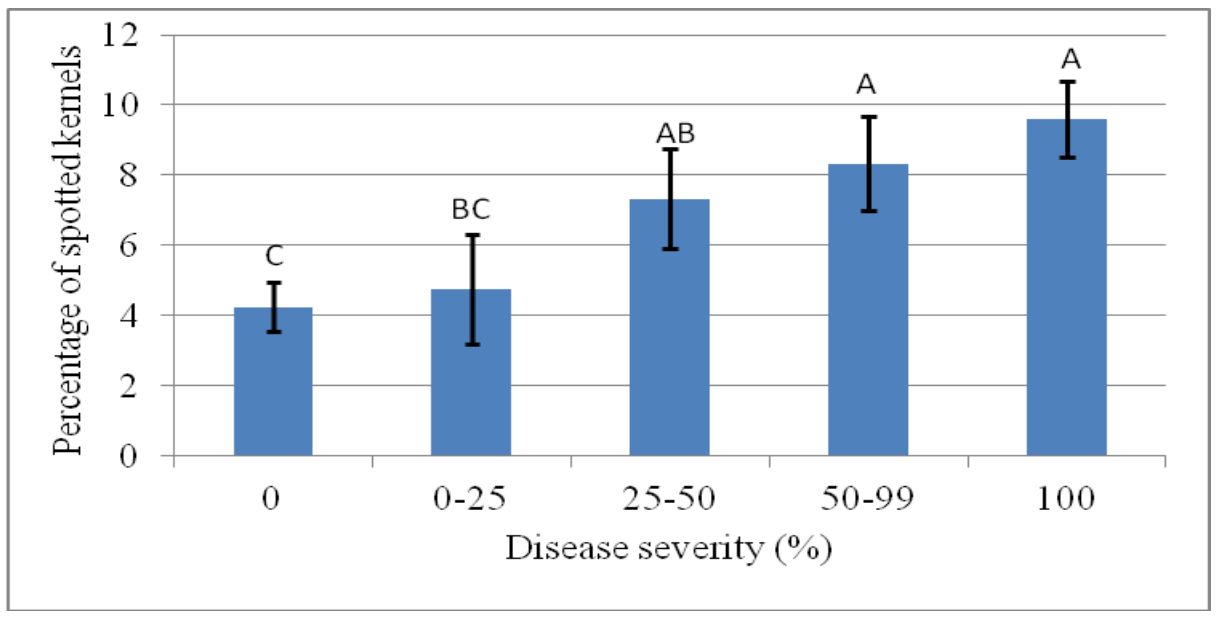

Figure 6. Effect of nut scarification associated with powdery mildew (Oidium anacardii 


\section{$\triangle$ Macrothink}

Noack) on percentage of spotted kernels. Same letter on top of the bar means that percentage means were not statistically different by Fisher's LSD test at alpha $=0.05$. Little bars on top of the others represent standard errors of the mean.

No statistical differences on percentage premature kernels means could be detected as result of powdery mildew (Oidium anacardii Noack) nut scarification (Table 4). However, the percentage of spotted kernels was significantly increased (Table 4). The means of spotted kernels per category of nut scarification varied from 4 to $10 \%$ (Figure 6). Thus, the maximum relative loss through spotted kernels was estimated as $55.6 \%$.

\subsection{Effect of powdery mildew on the percentage of peels}

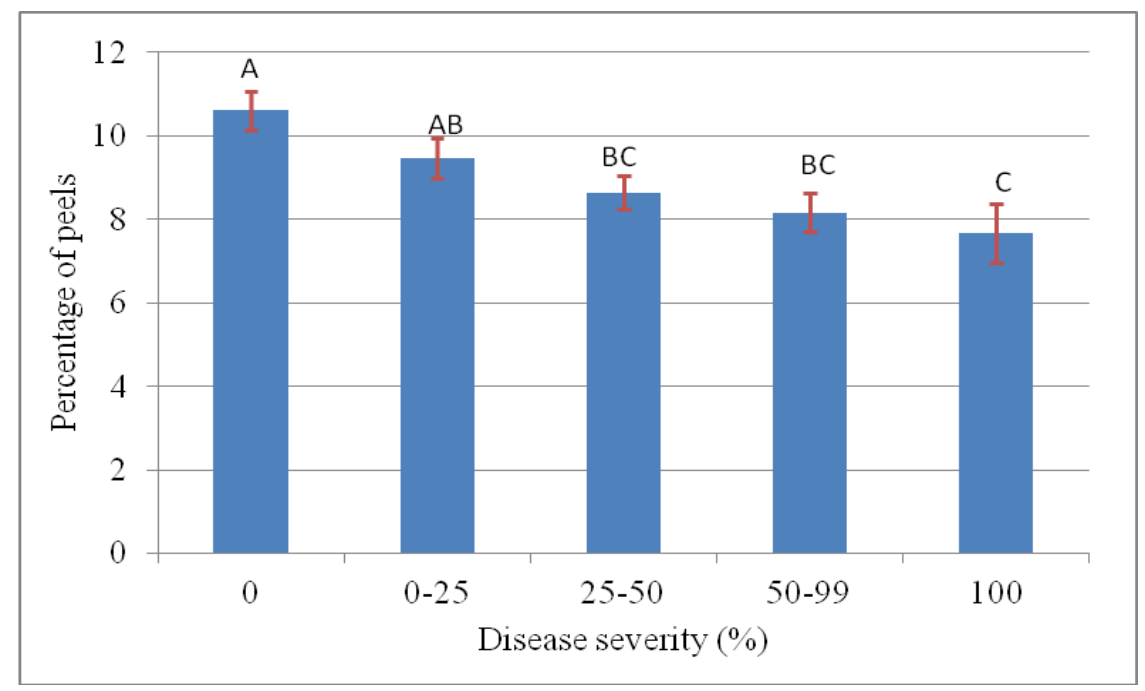

Figure 7. Effect of nut scarification associated with powdery mildew (Oidium anacardii Noack) on the amount of peels. Same letter on top of the bar means that treatment means were not statistically different by Fisher's LSD test at alpha $=0.05$. Little bars on top of the others represent standard errors of the mean.

Powdery mildew disease significantly reduced the percentage of kernel peels from 11 to $8 \%$ (Figure 7). Thus, the estimated relative maximum loss in peels due to nut scarification was $27.6 \%$.

\subsection{Effect of powdery mildew on international price of cashew nuts}

Based on scarification associated with powdery mildew, cashew nuts can be classified into three quality categories (Figure 8A, B and C). Category SA, consisting of un-scarified nuts or nuts with less that $50 \%$ of its surface scarified and thus requiring roughly 162 units to make up a kilogram of nuts with selling outturn of 44 pounds approximately. Category SB, when no distinction is made, that is, all nuts are mixed together. The nut count is around 172 units per kilogram with shelling outturn of 41 pounds (Figure 8B). Category SC: Nuts with more than $50 \%$ individual nut surface scarified; about 183 nuts per kilogram and 39 pounds of shelling outturn. When the shelling outturn was projected to increase by a unit and subsequent price increase by $0.02 \mathrm{USD} /$ pound (Figure $8 \mathrm{~B}$ ), the general impact of the disease was reflected in increased price of cashew nuts from 0.52 (price for scarified nuts) to 
0.57USD/kilogram (clean nuts or un-scarified) (Figure 8B).

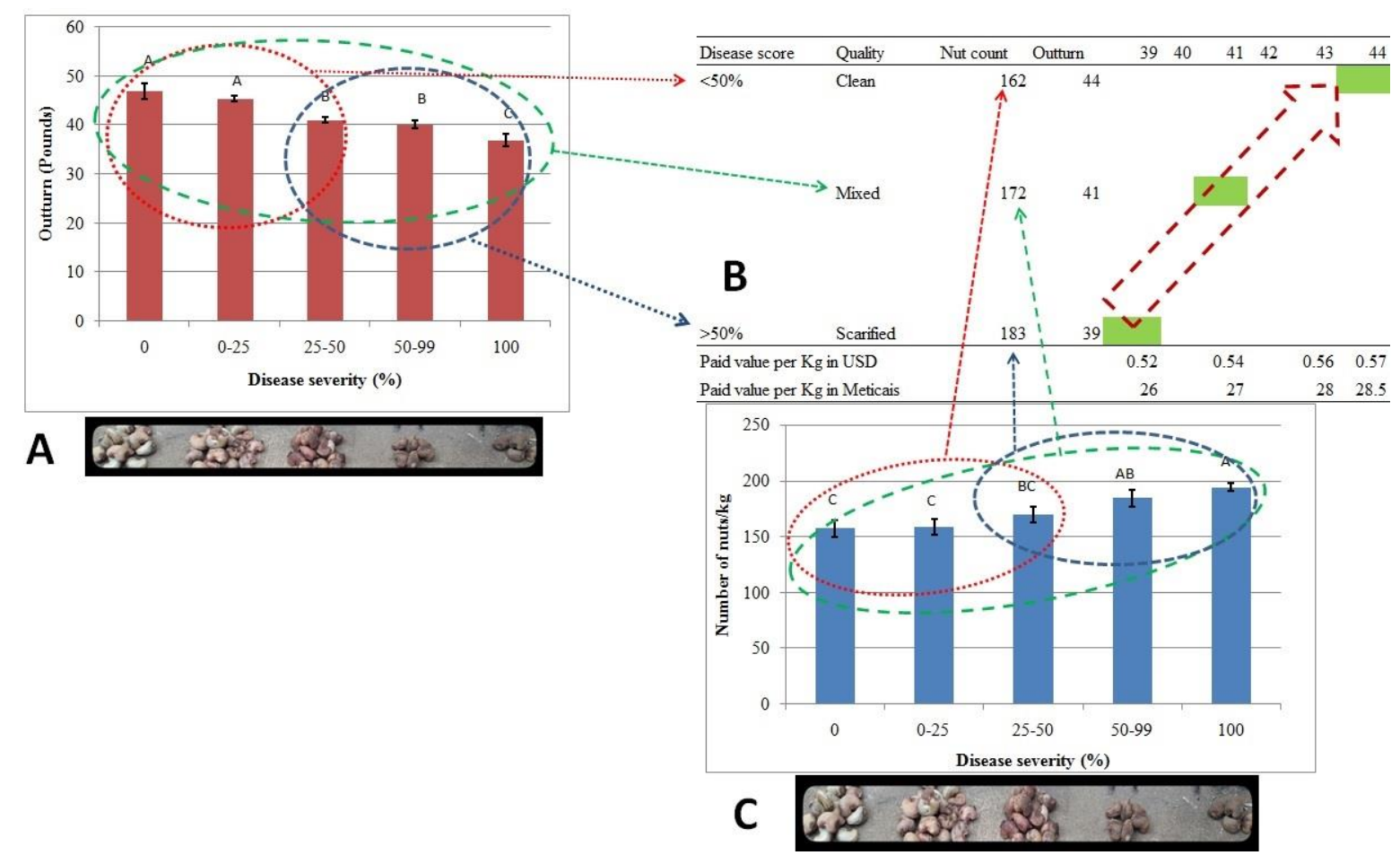

Figure 8. Powdery mildew (Oidium anacardii Noack) severity impact on shelling outturn (A), nut count $(\mathrm{C})$ and projected international price of cashew nuts (B). Means within the same cycle and color were not statistically different except when it covers all means to reflect all or mixed nuts. Little bars on top of the others (A \& C) represent standard errors of the mean.

\section{Discussion and Conclusion}

Disease attack in cashew is the main biological impediment factor to the supply of quality nuts to the industry (Dendena and Corsi, 2014). Among the diseases, powdery mildew $(O$. anacardii) associated with nut scarification symptoms, is the key in East Africa (Nathaniels, 1996). In this experiment, healthy nuts were found to be $34 \mathrm{~mm}$ long, $23 \mathrm{~mm}$ wide and 17 $\mathrm{mm}$ thick. These results are similar with those of Ogunsina and Bamgboye (2007) in Nigeria, who reported physical measurements of raw nuts of 30, 23 and $17 \mathrm{~mm}$ for length, width and thickness respectively. The present study also demonstrates that nut size and weight declined significantly under the effect of powdery mildew disease causing a relative maximum loss of $41.2 \%$ for nut length, $42.9 \%$ for nut width, $31.3 \%$ for nut thickness and $50 \%$ for nut weight. Nut weight loss associated with powdery mildew has been also reported in Brazil and it was demonstrated to vary between 5 and $27 \%$ depending on the crop genotypes. But the overall genotype means relative losses were 8 for nut length, 10 for nut width and $(-5) \%$ for nut thickness (Serrano et al., 2013). The negative value on thickness relative loss suggests an incremental effect of powdery mildew on nut thickness which is contrary to our finding. In general these losses are lower compared to our results. Indeed, Serrano and colleagues worked with two categories of nuts only: healthy and diseased. In the present study, diseased nuts were further demonstrated to cover a wide range of severity levels. When 
severely attacked, nuts reduce all of their physical measurements including thickness as previously recognized (Uaciquete, 2004). Furthermore, cashew populations, in most of cashew growing countries, are heterogeneous (Freire et al., 2002) and the rush for purchasing more nuts by processors always leads to bulking of nuts, regardless of genotypes. Therefore the role of cashew genotypes in cashew nut commercialization and processing is almost negligible. But the role of nut weight, among others, being an important component to cashew farmers, consumers and breeders (Dadzie et al., 2014) prevails.

From the industrial perspective, this work demonstrated that nut scarification significantly impacted the industrial processes by increasing the nut count and thus influencing the time required for cutting the nuts. In the present study the nut count was found to vary from 158 (clean) to 194 (diseased) units per kilogram. In Brazil, Serrano and colleagues (2013) found relatively lower values of 74 (clean) nuts $/ \mathrm{kg}$ and 89 (diseased) units $/ \mathrm{kg}$. This difference may be associated with the fact that the authors worked with improved cultivars. In Tanzania, nut count was found to vary between 125 and 152 units/kg between locations and 109 to 161 units/kg between varieties (Kasuga, 2013). Nut counts of 197 units/kg have been reported in Nigeria (Ogunsina, 2013). Therefore the results the present study follows between the minimum 109 nuts/kg and the maximum 197 nuts/kg previously reported by other researchers.

In Tanzania, the mean percentage kernel outturn has been found to vary between 26 and $29 \%$ depending of the genotype and site of production (Kasuga, 2013) and between 22 and $37.7 \%$ in Ghana, again depending on the genotype (Dadzie et al., 2014). In the present study the kernel outturn percentage varied between 26 and 33\% depending on the disease severity on nuts. The sampled nuts consisted of a mixer of multiple genotypes, therefore observed differences can be explained by the genotype and/or environment effect. This supports the finding by Kasuga (2013), who, in Tanzania, compared clones and respective half-sibs over different locations and showed the importance of genotype and environment on nut and kernel sizes. Furthermore, the genotype derived variations may have significantly contributed to the high coefficient of variations (CVs) obtained throughout this experiment. Similarly, high CV values were reported when cashew quantitative traits such as nut count, weight, (Chipojola et al., 2009).

Powdery mildew severity on nuts caused a shelling outturn relative maximum loss of $21.1 \%$ and total industrial kernel yield of $20.3 \%$. The highest maximum relative loss was observed in the percentage of white wholes $(88.1 \%)$. White wholes, is the reference class for cashew kernels in international market because it helps to predict income from specific lot of nuts (Ogunsina, 2013). Therefore, keeping high yield of white wholes is the key target for workers in the processing industry (Ogunsina and Bamgboye, 2007) and constitutes the basis for payment (Kanji et al., 2004). The loss of white wholes suggests that $O$. anacardii attack creates physic and chemical changes in the properties of the cashew nut shell leading to its higher crackability and subsequent breaking of kernels. Similar changes in physic properties of the nuts have been observed when cashew nuts were heat pre-treated before steam boiling (Ogunsina and Bamgboye, 2007). The present results indicate that yielding white wholes is highly decreased by the increased level of nut scarification. Therefore, daily quantity of nuts 
allocated, as targets for each worker to process, could be adjusted as function of scarification of the nuts being worked.

Significant statistical differences on the percentage of spotted were detected among the five levels of disease severity on the nuts. But high CV was observed. This is in conformity with the existing knowledge that that spotted kernels result from sucking insect, such as Helopeltis spp., damage on premature nuts (Ohler, 1979). Powdery mildew nut scarification may be facilitating insect damage.

The maximum relative loss due to rotten kernels was less than $1 \%$. The percentage of rotten nuts reaching the factory is commonly low. This is so, because the majority of farmers pick fallen nuts instead of harvesting (Gilleo et al., 2011). In general, post harvest rotting of cashew nuts can be traced back to pre-mature harvesting of nuts (Gyeadu-Akato et al., 2014). This research was conducted only two to three months after the harvesting season. Therefore, fungal rotting could be expected later. The approach followed in this research can be used to determine the effect of the disease on deterioration of stored nuts over time. This is important because nuts are normally stored for almost 12 months in order to maintain the factory in activity until the following crop (Gilleo et al., 2011; Gyeadu-Akato et al., 2014) .

We propose adoption of three nut scarification categories: SA (clean), SB (mixed) and SC (scarified) for cashew nuts entering the market. The importance of this approach is to help cashew processors to improve their projections of industrial yield, which is now based only on outturn test now shown to be affected by powdery mildew. Industrial measures arising from this approach may include adjustment, through research, for each category (SA, SB and SC) of the steaming time and cutting pressure in order to minimize loss of white wholes kernels. Farmers adopting the above suggested scale would benefit from improved farm gate price on their best quality nuts and thus be encouraged to work towards increased proportion of SA category in the field. In the long run, an appropriate and feasible technology for scarified nut sorting needs to be developed.

In order to reduce the amount of diseased nuts, farmers would have to secure minimum nuts damage in the field. Indeed, effective fungicides, against powdery mildew, have been developed and tested (Martin et al., 1998; Smith et al., 1997). However, lack of investment capital, application of incorrect dosage, improper timing of spray, reduced number of applications and limited skills to undertake field work, remains being the major problems encountered at farmers' level (Uwagboe et al. 2010; Kidunda et al., 2013; Muniu, 2013; Magani et al., 2015).

The effect of powdery mildew disease on biometric qualities of cashew nuts was first published by Millanzi (1998), from Tanzania. The author compared diseased and disease free nuts of different genotypes considering parameters such as nut weight, kernel weight and kernel outturn. Later, Serrano et al., 2013, in Brazil, worked with more parameters including nut size and kernel size and also compared healthy and diseased nuts from different genotypes. Both authors concluded that powdery mildew has negative impact on cashew nuts and this varies with the genotype (Millanzi, 1998 and Serrano et al., 2013). This paper is the first to report on post harvest categorization of powdery mildew nut severity with an aim of 
assessing direct impact of the disease throughout the industrial processing stages and to highlight the potential uses of the developed disease scale on others aspects of the cashew value chain.

By using the disease scale presented in this study we successfully demonstrated the negative impact of powdery mildew on cashew nut industrial processes. The potential utilization of the scale includes, the currently ongoing research, on the effect of the disease on cashew nut seed germination, deterioration of nuts in the warehouses and impact of the disease on nutritional components of the affected kernels. The knowledge generated will also help to create global awareness on the need to invest on improvement of disease management strategies at all levels of cashew value chain.

In conclusion, powdery mildew caused direct reduction of, among others, nut weight (50\%), outturn (21.1\%) and thus inducing high industrial relative yield losses with particular reference to the percentage of white wholes kernels (88.1\%). Adjustments in nut boiling time and cutting pressure, through research is recommended. Similarly, a three category sorting system based on nut scarification is required. The system will help cashew nut processors to better predict their income and reduce losses estimated as $10 \%$ based on nut count and outturn. Farmers will be encouraged to adopt measures that reduce disease incidence and severity on the nuts through better price for better quality as demonstrated in this study.

\section{Acknowledgement}

The research was financed by the Government of Mozambique through co-support of the National Cashew Promotion Institute (INCAJU) and the National Agriculture Research Institute (IIAM) without which this research could not have been done. Thanks for Dr. Leonel Moiana (IIAM senior researcher) for his valuable comments on the manuscript. Thanks to Mr. Americo Marques, Manager of CondorNuts cashew processing company for the authorization and support given in factory. To all workers who contributed with their skills, our sincere gratitude.

\section{References}

Adeigbe, O. O., Olasupo, F. O., Adewale, B. D., \& Muyiwa, A. A. (2015). A review on cashew research and production in Nigeria in the last four decades. Scientific Research and Esseys, 10 (5),196-209. Http://dx.doi.org/10.5897/SRE2014.5953.

Chopojola, F. M., Mwase, W. F., Kwapata, M. B., Bokosi, J. M., Njoloma, J. P., \& Maliro, M. P. (2009). Morphological characterization of cashew (Anacardium occidentale L.) in four populations in Malawi. African Journal of Biotechnology, 8(20),5173-5181. Http://dx.doi.org/10.5897/AJB09.653. http://www.academicjournals.org/AJB.[online]. March, 2016.

Dadzie, A.M., Adu-Gyamfi, P.K.K.,Opuku, S.Y., Yeboah, J., Akpertey, A., Opuku-Ameyau, K., Assuah, M., Gyedu-Akoto, E. \& Danquah, B. (2014). Evaluation of potential cashew clones for utilization in Ghana. Advances in Biological Chemistry, 4, 232-239. http://dx.doi.org/10.436/abc.2014.44028.[online]. March, 2016. 
Dendena, B. \& Corsi, S. (2014). Cashew, from seed to market: A review. Agronomy for sustainable development, 34(4), 753-772. Http://dx.doi.org/ 10.1007/S13593-014-0240-7. https://hal.archives ouvertes.fr//hal-01234842 [online]. March, 2016.

Freire, F.C.O., Cardoso, J.E., Dos Santos, A.A. \& Viana, F.M.P. (2002). Diseases of cashew nut plants (Anacardium occidentale L.) in Brazil. Crop Protection, 21(6),489-494. onlinelibrary.wiley.com/doi/10.1046/j.1365-3059.1999.00363.x

Gilleo, J., Jassey, K \& Sallah, J.N. (2011). Cashew business basics. The Gambia river basin cashew value chain enhancement project (CEP). IRD-International reflief and development. http://www.africancashewalliance.com/sites/default/files/documents/cashew_12oct2011.pdf [online]. March, 2016.

Gyeadu-Akato, E., Lowor, S.T., Assuah, M., Kumi, W., \& Dwomoh, E. (2014). Assessment of post-harvest handling effects on quality of cashew nuts and kernels in Ghana. Journal of Scientific Research \& Reports, 3(7), 953-965. http://dx.doi.org/10.9734/JSRR/2014/8242. [online]. March, 2016.

Initini, M. (1987). Phytopathological aspects of cashew (Anacardium occidentale L.) in Tanzania. International Journal of Tropical Plant Disease, 5(2), 115-130.

Kanji, N., Vijfhuizen, C., Artur, L. \& Braga, C. 2004. Liberalisation, gender and livehoods: The Mozambique csahew nut case. Summary report. International Institute for Environment and Development. Nederlanden.

Kasuga, L. J. (2013). Performance of improved and local cashew (Anacardium occidentale L.) genotypes under on-farm conditions in South-East Tanzania. In: Proceedings of the Second international cashew conference. Cashew, People and Environment. Kampala, Uganda, 26-29 April, 2010 [ed. by Masawe,P.A.L., Esugu, J.F.O., Kasuga, L. J., Mneney, E.E. \& Mujuni, D.]. 95-102.

Kasuga, L. J., Topper, C.P., Martin, P.J., Boma, F., Waal Dde., \& Bakari, J.J. (1998). Integrated cashew management: approprate strategies for increasing productivity of smallholder cashew. In: Proceedings of the international cashew and coconut conference. Dar es Salaam, Tanzania, 17-22 February, 1997 [ed. by Topper, C. P., Caligari, P. S.D., Kullaya, A. K., Shomari, S. H., Kasuga, L. J., Masawe, P. A. L. \& Mpunami, A. A.]. 71-73.

Kidunda, B.R., Kasuga, L.J., Magani, S.F. \&Mwakanyamale, D.F. (2013). Adoption of cashew production technologies by farmers in the southeastern Tanzania. International conference on food and agriculture sciences 55, 94-99. IACSIT Press, Singapore. http://dx.doi.org/10.7763/IPCBEE.2013.V55.18

Magani, S.F., Nene, W. \& Shomari, S.H. 2015. Assessing factors limiting the adoption of pesticides use in technologies in cashew production. A case study in Mtwara District Tanzania. In: Book of abstracts of the $3^{\text {rd }}$ international cashew conference. Cashew for Health, Wealth and Environment. Dar es Salaam, Tanzania, 16-17 ${ }^{\text {th }}$ November, 2015 . Page 21.

Martin, P.J., Kasuga, L. J. \& Bashiru, R.A. (1998). Cashew farm upgrading: Agronomic 
options for increasing cashew production by smallholder farmers in Tanzania. Experimental Agriculture 34(2), 137-152, http://dx.doi.org/10.1017/S0014479798002014.

Martin, P.J., Topper, C.P., Bashiru, R.A., Boma, F., De Waal, D., Harries, H.C., Kasuga, L.J., Katanila, N., Kikoka, L.P., Labibal, R., Maddison, A.C., Magule, A. E. \& Stathers, T. (1997). Cashew nut production in Tanzania. Constraints and progress through integrated crop management.Crop Protection,16(1),5-14. http://dx.doi.org/10.1016/S0261-2194(96)00067-1

Masawe, P.A.L., Cundall, E.P. \& Caligari, P.D.S. (1997). Powdery mildew (Oidium anacardii) onset and development of flowering panicles of cashew clones (Anacardium occidentale L.) as ameasure of clone resistance. Tropical Agriculture, 79,229-234. http://agris.fao.org/agris-search/search.do?recordID=TT2000000061.[online]. March, 2016.

Millanzi, K.J.K. (1998). The effect of powdery mildew disease and storage practices on quality and viability of cashew nuts. In: Proceedings of the international cashew and coconut conference. Dar es Salaam, Tanzania, 17-22 February, 1997 [ed. by Topper, C. P., Caligari, P. S.D., Kullaya, A. K., Shomari, S. H., Kasuga, L. J., Masawe, P. A. L. \& Mpunami, A. A.]. 151-153.

Mitchell, J. D., \& Mori, S. A. (1997). The cashew and its relatives (Anacardium: Anacardiaceae). The New York Botanical Garden. New York.

Mneney, E. E. (2013). Integrated cashew management: approprate strategies for increasing productivity of smallholder cashew. In: Proceedings of the Second international cashew conference. Cashew, People and Environment. Kampala, Uganda, 26-29 April, 2010 [ed. by Masawe,P.A.L., Esugu, J.F.O., Kasuga, L. J., Mneney, E.E. \& Mujuni, D.]. 51-58.

Muniu, F. K., Oyange, W., Ngugi, T.D., Ndungu, J., Mwinga, W. S., \& Mwashumbe, S. (2013). Dissemintion of cashew management technologies in Coastal kenya. In: Proceedings of the Second international cashew conference. Cashew, People and Environment. Kampala, Uganda, 26-29 April, 2010 [ed. by Masawe,P.A.L., Esugu, J.F.O., Kasuga, L. J., Mneney, E.E. \& Mujuni, D.]. 105-108.

Nathaniels, N.Q.R. (1996). Methods, including visual keys for assessment of cashew powdery mildew (Oidium anacardii Noack) severity. Short communication. International Journal of Pest Management, 42 (3), 199-205.

http://dx.doi.org/10.1080/09670879609371994.

Ogunsina, B. S. \& Bamgboye, A. L. (2007). Effects of pre-shelling treatment on physical properties of cashew nut (Anacardium occidentale). International Agrophysics,21(4), 385-389.http://www.old.international-agrophysics.org/en/issues.html? stan=detail\&vol=21\&n umer=4\&paper=686\&i=10. [Online]. March, 2016.

Ogunsina, B.S. (2013). Crackability and chemical composition of pre-treated cashew nuts using a hand-operated knife cutter. Agricultural Engineering International: CIGR Journal ,15, 275-283. http://www.cigrjournal.org/index.php/Ejounral/article/view/2438/1721[online].

March, 2016. 


\section{MInstitute Macrothink $_{\text {Int }}$}

Journal of Agricultural Studies

ISSN 2166-0379

2016, Vol. 4, No. 3

Ohler, J. G. (1979). Cashew. Comunication no. 71. Department of Agricultural Research of Royal Tropical Institute Press. Amstardam.

Petersen, R.G. (1994). Agricultural field experiments: Design and analysis. Marcel Dekker, Inc. New York.

Samal, S., Rout, G.R. \& Lenka, P.C. (2003). Analysis of genetic relationships between populations of cashew (Anacardium occidentale L.) by using morphological characterization and RAPD markers. Plant Soil and Evironment, 49(4), 176-182.

http://www.agriculturejournals.cz/publicFiles/52847.pdf [Online]. March, 2016.

Serrano, L.A.L., Neto, F. C. V., Melo, D. S. \& Cardoso, J. E. (2013). Influência do oidio nas castanhas de diferentes genótipos do cajeuiro. [Influence of the powdery mildew in cashew nuts genotypes]. Embrapa 40. Boletim de Pesquisa e Desenvolvimento, V Serie, 76(1), 1-22. http://www.cnpat.embrapa.br/download_publicacao.php?id=434.[online]. March, 2016.

Shomari, S.H. \& Kennedy, R. (1999). Survival of Oidium anacardii on cashew (Anacardium occidentale) in southern Tanzania. Plant Pathology, 48(4),505-513. http://dx.doi.org/10.1046/j.1365-3059.1999.00363.x .

Shomari, S. H. (1996). Studies on the biology and epidemiology of oidium anacardii Noack, the powdery mildew pathogen of cashew. $\mathrm{PhD}$ thesis. University of Birmingham, Birmingham, UK.

Sijaona, M. E. R. \& Mansfield, J. W. (1999). Structural resistance of cashew (Anacardium occidentale) against powdery mildew (Oidium anacardii). Tanzania Journal of Agricultural Science, 2(1), 115-12. http://eurekamag.com/research/003/568/003568453.php [online]. March, 2016.

Smith, D.N., King, W.J., Topper, C.P., Mhando, H. \& Cooper, J.F. (1997). Studies on spray deposition on cashew trees in Tanzania with reference to the use of fungicides to control Oidium anacardii. Crop Protection, 16(4), 313-322.

http://dx.doi.org/10.1016/S0261-2194(97)00005-7.

Topper, C.P., Martin, P.J., Katanila, N., Kikoka, L.P., Lamboll, R., Masawe, P.A.L. \& Shomari, S.H. (1998). The historical and institutional background of the Tanzania cashew industry. In: Proceedings of the international cashew and coconut conference. Dar es Salaam, Tanzania, 17-22 February, 1997 [ed. by Topper, C. P., Caligari, P. S.D., Kullaya, A. K., Shomari, S. H., Kasuga, L. J., Masawe, P. A. L. \& Mpunami, A. A.]. 78-83.

Uaciquete, A. (2004). Epidemiology and control of powdery mildew (Oidium anacardii Noack) on cashew (Anacardium occidentale L.) in Mozambique. M Sc. Thesis, University of Pretoria, Pretoria, South Africa.

Uwagboe, E.O., Adeogun, S. O., \& Odebode, S.O. (2010). Constraints of farmers in cashew production: A case study of Orire L.G.A. of Oyo State, Nigeria. ARPN Journal of Agricultural and Biological Science, 5(4), 27-31.

http://www.arpnjournals.com/jabs/research_papers/rp_2010/jabs_0710_201.pdf [online]. 
March, 2016.

Waller,J., Nathaniels, N., Sijaona, M.E.R. \& Shomari, S.H. (1992). Cashew powdery mildew (Oidium anacardii Noack) in Tanzania. Tropical Pest Management, 38(2),160-163. http://dx.doi.org/10.1080/09670879209371675.

Zhongrun, Z., Lihong, L., \& Uaciquete, A. (2013). Diseases and insect pests of cashew in Mozambique. Tropical Crops Genetic Resources Research Institute, CATAS. China Agriculture Press.

\section{Copyright Disclaimer}

Copyright for this article is retained by the author(s), with first publication rights granted to the journal.

This is an open-access article distributed under the terms and conditions of the Creative Commons Attribution license (http://creativecommons.org/licenses/by/3.0/). 